\title{
Left anterior descending coronary artery dissection during ventricular tachycardia ablation - case report
}

\author{
KRESIMIR KORDIC, SIME MANOLA, IVAN ZELJKOVIC, IVICA BENKO, NIKOLA PAVLOVIC \\ University Hospital Center Sisters of Charity, Department of Cardiology, Zagreb, Croatia
}

\begin{abstract}
Fascicular left ventricular tachycardia (VT) is the second most frequent idiopathic left VT in the setting of a structurally normal heart. Catheter ablation is curative in most patients with low complication rates. We report a case of ostial left anterior descending coronary artery (LAD) occlusion during fascicular ventricular tachycardia ablation.

Dissection was the most likely cause of LAD obstruction. To the authors' best knowledge, this is the first case reporting selective LAD dissection during electrophysiology study with no left main coronary artery (LMCA) affection.
\end{abstract}

Key words: ventricular tachycardia, electrophysiology, radiofrequency catheter ablation, ST elevation myocardial infarction, percutaneous coronary intervention.

\section{INTRODUCTION}

Fascicular left ventricular tachycardia (VT) is the second most frequent idiopathic left VT, after left ventricular outflow tract VT, occurring in the setting of a structurally normal heart [1].

According to current ESC guidelines [2], catheter ablation is curative in most patients with VT without overt structural heart disease, with low complication rates (around 3\%) [3]. Complications include access site vascular complications, thromboembolism, atrioventricular block, myocardial perforation, valvular damage, myocardial infarction and death.

We report a case of left anterior descending coronary artery (LAD) dissection during fascicular VT ablation.

\section{CASE REPORT}

A 36-year old man with no medical history presented to the Emergency Department (ED) with palpitations, dyspnea and presyncope.

Blood pressure was $90 / 60 \mathrm{mmHg}$ and heart rate was $210 \mathrm{bpm}$. The electrocardiogram revealed wide QRS tachycardia with superior axis and right bundle branch block morphology. Intravenous adenosine and propafenone had no effect on tachycardia. Conversion to sinus rhythm was achieved with intravenous verapamil.
An electrocardiogram following cardioversion showed normal sinus rhythm, without preexcitation or conduction abnormalities. There was no structural heart disease found on transthoracic echocardiography.

An electrophysiology study was performed using right femoral approach. During the tachycardia, His was activated after the ventricular activation and tachycardia could be entrained from atrium and the ventricle. Based on these findings, the diagnosis of fascicular ventricular tachycardia was established.

Mapping and ablation was performed using 3D mapping with Carto 3D system. The LV was mapped using retrograde approach. Aortic valve was crossed after several attempts with catheter completely bent.

During the mapping of the LV, the patient became upset, pale and sweaty. Blood pressure was $130 / 80 \mathrm{mmHg}$ and heart rate $170 \mathrm{bpm}$. Electrocardiogram revealed non-sustained VT, but, during the sinus rhythm, ST-segment elevation in V1-V5 leads was noted (Figure 1). Urgent coronary angiography was performed. LAD was occluded at the ostium and the finding was suggestive of F-type dissection (Figure 2). Wire was placed in distal LAD and several balloon dilatations were performed with no effect. After attempted thrombus aspiration, heparinization and administration of nitroglycerin, no blood flow was restored in the LAD. Drugeluting (DE) stent was implanted in the proximal 
segment of LAD, but the flow was restored only to the end of the stent (Figure 3). Additional balloon dilatation of the distal segment had no effect. After that, another DE stent was implanted just distal to the previously implanted stent, and the TIMI III flow was restored in the LAD (Figure 4).

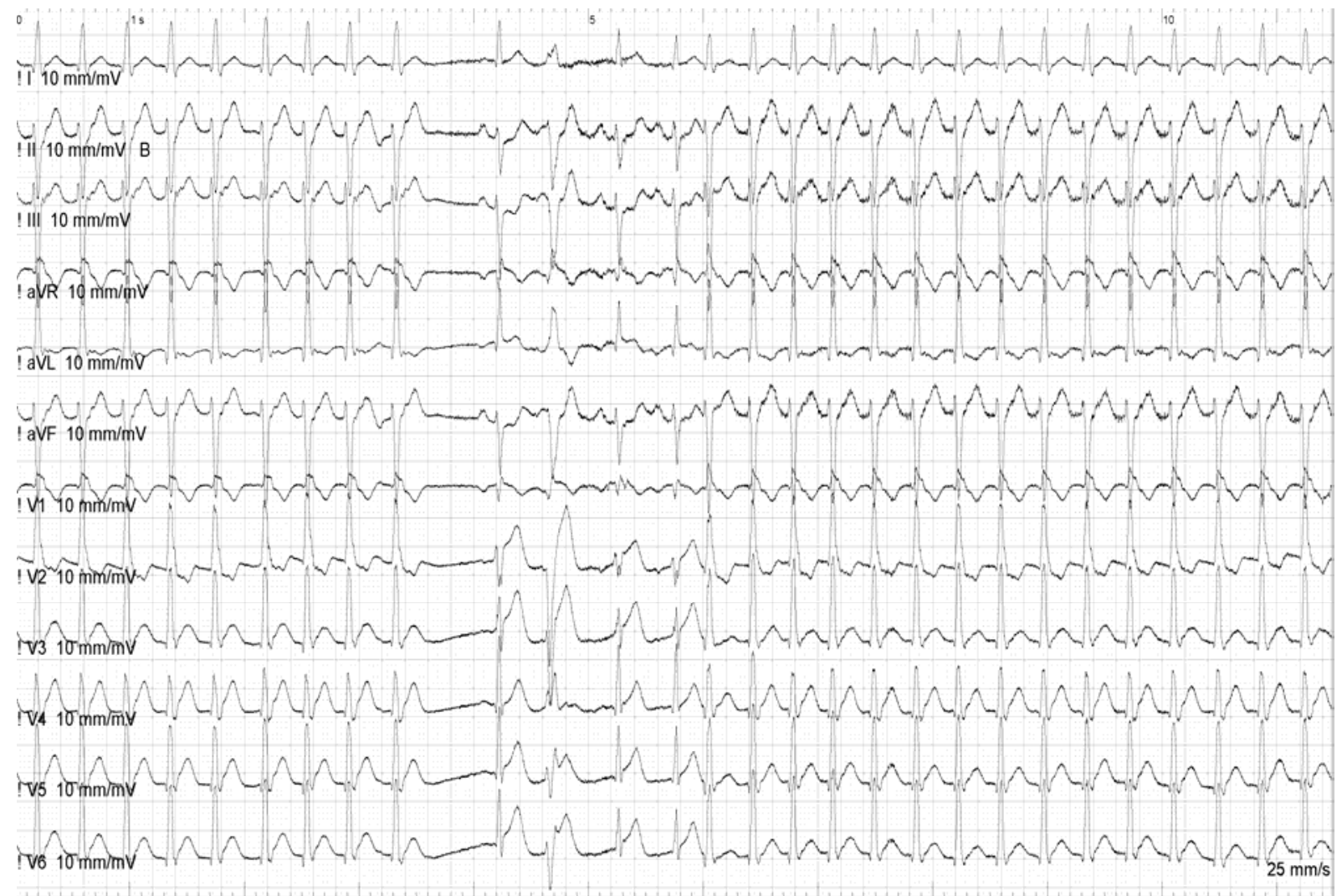

Figure 1. ECG after ablation: Non-sustained ventricular tachycardia, ST-segment elevation in V1-V5 during sinus rhythm.

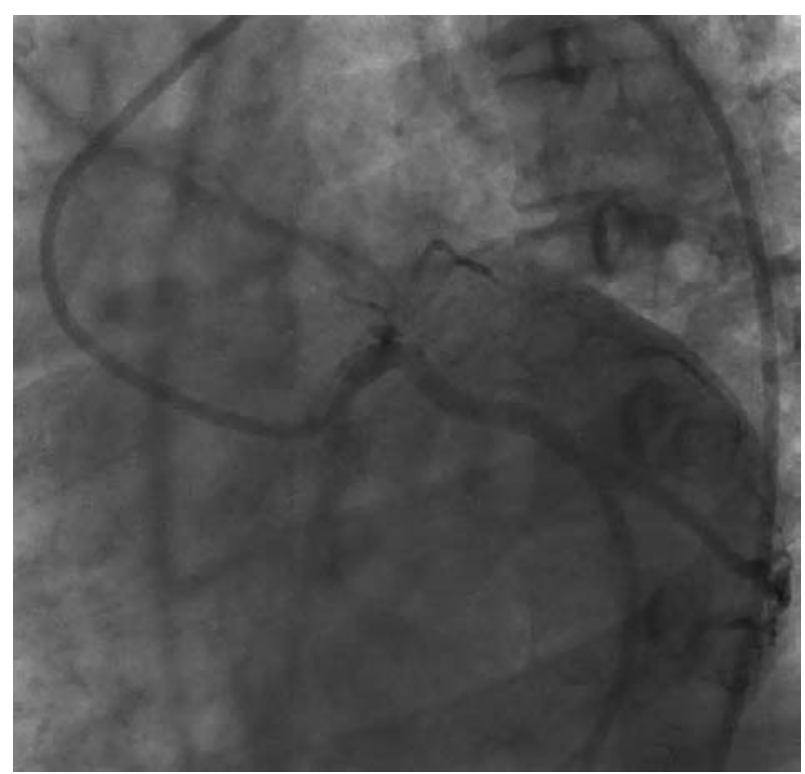

Figure 2. Coronary angiography initial finding (LAO 50 caudal $30^{\circ}$ ): No flow in LAD.

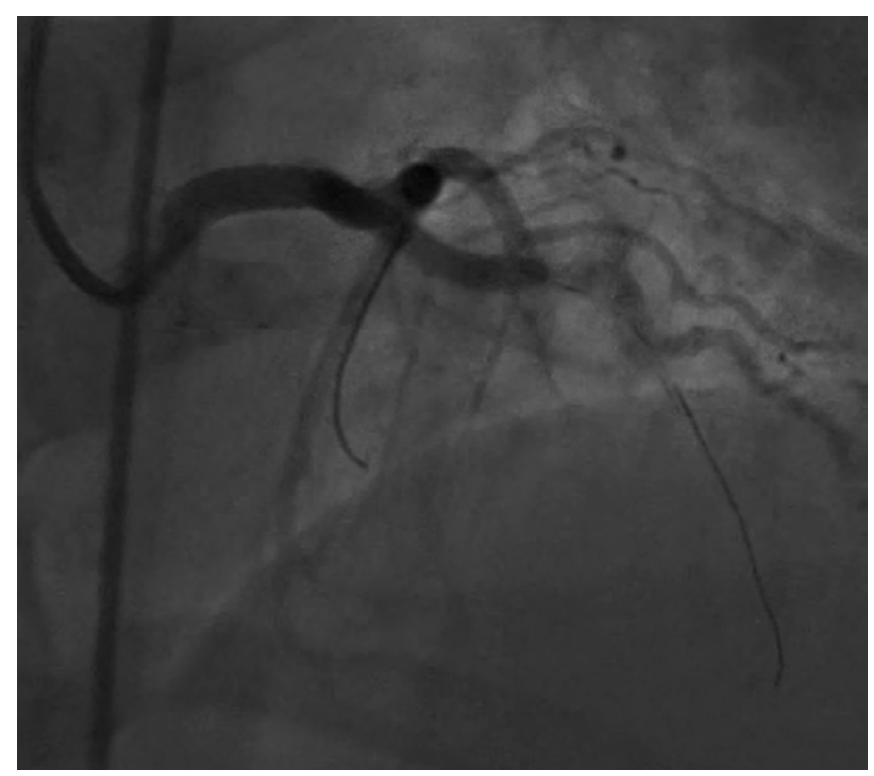

Figure 3. Coronary angiography $\left(\operatorname{RAO} 30^{\circ}\right.$, cranial $\left.30^{\circ}\right)$ : After balloon dilation (2,5/15), a drug-eluting (DE) stent (3.5/24) was implanted in the proximal part of LAD, but the flow was restored only to the end of the stent. 


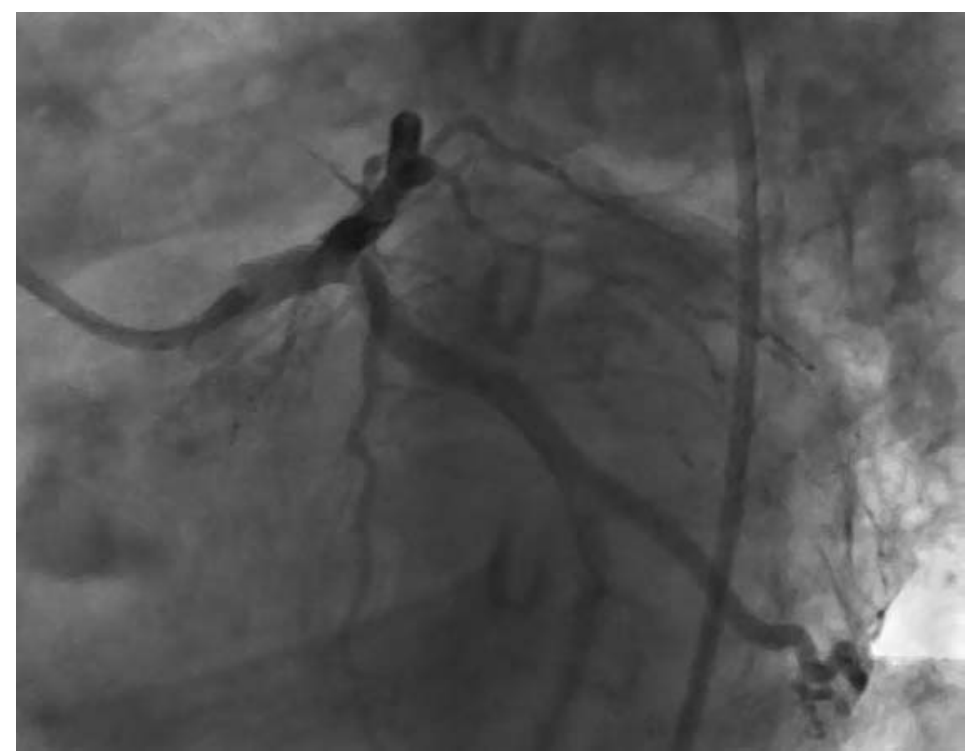

Figure 4. Final coronary angiogram (LAO 50 $0^{\circ}$ caudal $\left.30^{\circ}\right)$ : Another DE stent (3.0/24) was implanted immediately distally to the previously implanted stent, and the TIMI III flow was restored.

Total ischemia time was less than 45 minutes. However, laboratory findings following coronary angiography showed high-sensitive cardiac troponin I > $50000 \mathrm{ng} / \mathrm{L}$, and creatine-kinase $2817 \mathrm{U} / \mathrm{L}$. Echocardiography revealed hypokinesia of the distal part of the interventricular septum, with preserved systolic function of the LV. Until discharge, there were no arrhythmias noted and the patient was in NYHA functional class I. The patient was discharged with clopidogrel, acetylsalicilic acid (ASA), zofenopril, bisoprolol and pantoprazole.

On follow-up visit 3 months later, echocardiography revealed no regional hypokinesia. The patient had no palpitations and 24-hour ECG recording was uneventful.

Five months later, the patient presented to ED with VT, which was converted to sinus rhyhtm with intravenous verapamil. On follow-up visit 12 months later, the patient was asymptomatic for palpitations in NYHA functional class 1 and ambulatory ECG recording was uneventful. Coronary angiography was repeated 15 months later and there were no hemodynamically significant stenoses of coronary arteries found. The patient remained asymptomatic for palpitations and in NYHA functional class 1 with chronic therapy verapamil and ASA.

\section{DISCUSSION}

Coronary artery occlusion is a rare (incidence less than $0.2 \%$ ) complication of RF catheter ablation
[4]. Spasm is postulated to be the most common mechanism [5]. Additionally, it may be caused by direct thermal damage from RF energy, dissection due to catheter manipulation, thermal impact or thromboembolism.

In our patient, mapping of the LV was performed using the retrograde approach. The procedure was complicated with development of ST segment elevation myocardial infarction with occlusion of the ostial LAD. In this case, possible mechanisms include thrombus formation and embolization of the LAD or mechanical trauma/dissection with catheter manipulation during several attempts to cross the aortic valve. Coronary angiography revealed occlusion of the ostial LAD while the left main and circumflex arteries were normal. Thromboembolism was suspected first, because of the occlusion of the LAD without LMCA affection.

During the percutaneous coronary intervention, the LAD could not be opened with heparinization, attempted thrombus aspiration and balloon predilatation. Also, the positioning of the wire in the distal LAD was very difficult, making dissection the most likely cause of LAD obstruction.

To the authors best knowledge, this is the first case reporting selective LAD dissection with no LMCA affection during electrophysiology study. Several authors described cases of LMCA dissection, which is anatomically much more likely [6-10].

Although the overall risk of coronary artery complications during RF ablation is low, this case 
illustrates the importance of careful catheter manipulation especially when crossing the aortic valve during retrograde approach. Coronary artery dissection can be avoided using the transseptal approach which, however, has other potential complications.

Conflict of interest. The authors declare that there are no conflicts of interest.

Tahicardia ventriculară fasciculară stângă (VT) este cea de-a doua cauză ca frecvență de tahicardie stângă idiopatică la un pacient cu structură cardiacă normală. Ablația prin cateterizare are rol curativ la majoritatea pacienților cu o rată scăzută a complicațiilor. Prezentăm cazul unei ocluzii ostiale a arterei coronare descendente anterioare stângi (LAD) în timpul procedurii de ablație a tahicardiei.

Cea mai probabilă cauză a obstrucției LAD a fost disecția arterei. Acesta este primul caz raportat de disecție a LAD în timpul studiului electrofiziologic fără afectarea trunchiului arterei coronare stângi (LMCA).

Correspondence to: Kordic Kresimir, M.D. University Hospital Center Sisters of Charity, Department of Cardiology Vinogradska cesta 29, 10000 Zagreb, Croatia, Tel.: +385981921263

E-mail: kordic.kresimir@yahoo.com

\section{REFERENCES}

1. ZIPES DP, JALIFE J. Cardiac electrophysiology: from cell to bedside (Sixth edition). Elsevier, Philadelphia, 2014:827.

2. PRIORI SG, BLOMSTRÖM-LUNDQVIST C, MAZZANTI A, BLOM N, BORGGREFE M, CAMM J et al. 2015 ESC Guidelines for the management of patients with ventricular arrhythmias and the prevention of sudden cardiac death. Eur Heart J. 2015; 36(41):2793-867.

3. BOHNEN M, STEVENSON WG, TEDROW UB, MICHAUD GF, JOHN RM, EPSTEIN LM et al. Incidence and predictors of major complications from contemporary catheter ablation to treat cardiac arrhythmias. Heart Rhythm $2011 ; \mathbf{8}: 1661$.

4. CALKINS H, SOUSA J, EL-ATASSI R, ROSENHECK S, DE BUITLEIR M, KOU WH et al. Diagnosis and cure of the WolffParkinson-White syndrome or paroxysmal supraventricular tachycardias during a single electrophysiologic test. $\mathrm{N}$ Engl J Med 1991; 324:1612-1618.

5. YALIN K, GOLCUK E, BILGE AK, UMMAN S, ADALET K. Successful stenting of a left main coronary artery occlusion as a complication of RF ablation for Wolff-Parkinson-White syndrome. Pacing Clin Electrophysiol. 2012; 35(2):e43-6.

6. KOSINSKI DJ, BURKET MW, DURZINSKY D. Occlusion of the left main coronary artery during radiofrequency ablation for the Wolff-Parkinson-White syndrome. Eur J Card Pacing Electrophysiol 1993; 3:63-6.

7. HOPE EJ, HAIGNEY MC, CALKINS H, RESAR JR. Left main coronary thrombosis after radiofrequency ablation: successful treatment with percutaneous transluminal angioplasty. Am Heart J 1995; 129:1217-9.

8. PONS M, BECK L, LECLERCQ F, FERRIERE M, ALBAT B, DAVY JM. Chronic left main coronary artery occlusion: A complication of radiofrequency ablation of idiopathic left ventricular tachycardia. Pacing Clin Electrophysiol 1997; 20: 1874-1876.

9. KHARRAT I, CHARFEDDINE H, SAHNOUN M, REKIK S, KRICHEN S, HENTATI M, KAMMOUN S. Left main coronary thrombosis: Unusual complication after radiofrequency ablation of left accessory atrioventricular pathway. $\mathrm{J}$ Electrocardiol 2008; 41:683-685.

10. JANEIRA LF. Coronary artery dissection complicating radiofrequency catheter ablation via the retrograde approach. Pace 1998; 21:1327.

Received June 13, 2017 